\title{
En diagnostisk revolusjon
}

Behandling av medfødte sammenvokste fingre, syndaktylier, omtales i dette nummer av Tidsskriftet (1). I likhet med andre medfødte strukturelle anomalier kan syndaktylier være et isolert fenomen eller ledd $i$ et medfødt syndrom. Når noe er galt med barnet, spør gjerne foreldrene: Hvorfor skjedde det? Hvordan vil det gå? Hva kan gjøres? Kan det skje igjen? En årsaksdiagnose er ingen fasit, men et godt utgangspunkt for å svare.

Tusenvis av medfødte syndromer er beskrevet. Når årsaken er kjent, er den ofte genetisk. Mistanke om et medfødt syndrom oppstår ved en kombinasjon av faktorer som avvikende vekstmønster, uvanlige fysiske trekk, organmisdannelser, forsinket utvikling og kognitive vansker. Familieanamnesen kan gi informasjon om eventuelle slektninger med liknende problemer og om slektskap mellom foreldrene. I noen tilfeller kan man etter en del tankearbeid komme frem til en sannsynlig diagnose som for eksempel Williams syndrom, PraderWillis syndrom eller Angelmans syndrom og deretter rekvirere målrettet testing av ett eller noen få gener. Men selv i de beste hender lykkes denne diagnostiske tilnærming - fra fenotype til genotype i knapt halvparten av tilfellene. Nå skjer det et paradigmeskifte: Gentesting gjøres først, tankearbeid etterpå og mange flere vil få diagnose.

Hver for seg er medfødte misdannelser og syndromer sjeldne, men sammenlagt er de hyppige. Hos ca. $8 \%$ av levendefødte barn påvises en medfødt anomali og/eller et genetisk betinget syndrom innen 25 års alder (2). Genetiske årsaker til medfødte syndromer deles i to hovedkategorier som overlapper noe: enkeltgenfeil og kromosomavvik. Det sistnevnte involverer som oftest flere gener. Over halvparten av alle kromosomavvik er usynlige i lysmikroskopet, men kan påvises ved DNA-baserte kromosomanalyser. Samlet sett er slike submikroskopiske kromosomavvik langt hyppigere enn for eksempel Downs syndrom.

Strategien ved mistanke om et genetisk syndrom har hittil vært å teste ett eller flere utvalgte gener basert på det kliniske bildet. Denne strategien kan være svært ressurskrevende, men velges fordi en spesifikk diagnose kan ha konsekvenser for prognose, behandling og familieplanlegging. Det som er nytt, er at gentesting vil flyttes langt frem i diagnostiseringsprosessen. Når mistanke om et medfødt syndrom vekkes, vil gentesting ofte rekvireres før man har forslag til spesifikk diagnose. Flere diagnoser vil stilles og de vil stilles mye raskere enn tidligere. Mye av det diagnostiske tankearbeidet vil skje etter istedenfor $f ø r$ gentestingen. Dette er en følge av ny sekvenseringsteknologi, ofte kalt neste generasjons sekvensering, som gjør det mulig å undersøke et utvalg av eller alle våre 22000 gener samtidig.

Pris for laboratorieundersøkelsen, mangel på egnede bioinformatiske verktøy og sykehusansatte bioinformatikere, mangler i databaser over normale og patologiske genvarianter, lang svartid og suboptimal analysesensitivitet har hindret innføring av neste generasjons sekvensering. Disse problemene er nå i ferd med å løses takket være internasjonalt samarbeid og kontinuerlig metodeutvikling.

En bekymring knytter seg til påvisning av såkalt utilsiktede funn, dvs. genvarianter som kan ha helsemessige konsekvenser, men som ikke har sammenheng med problemstillingen pasienten utredes for. Hos en nyfødt som utredes for et medfødt syndrom, kan man for eksempel komme til å påvise en genfeil assosiert med betydelig økt sannsynlighet for kreftsykdom i voksen alder. Slike utilsiktede funn vil sannsynligvis forekomme hos noen få prosent av dem som undersøkes. Problemstillingen er ikke ny: Det gjøres også uventede funn ved for eksempel cerebral MR- eller DNA-analyse for submikroskopisk kromosomavvik. Utilsiktede funn ved genetiske undersøkelser bør kunne håndteres innenfor rammen av lege-pasient-forholdet. Muligheten for og tilnærmingen ved eventuelle funn må legen diskutere med pasienten eller foresatte før undersøkelsen rekvireres. Arbeidet med retningslinjer rundt dette er i gang (3).

Å kombinere klinisk ekspertise, neste generasjons sekvensering og bioinformatisk databearbeiding er en god diagnostisk strategi. En amerikansk forskergruppe har vist at det lar seg gjøre å anvende neste generasjons sekvensering til rask diagnostikk av syke nyfødte til en overkommelig pris (4). Ved The National Institutes of Health Undiagnosed Diseases Program var denne metoden avgjørende for å kunne stille diagnosen hos seks av 32 pasienter som tidligere var godt utredet med konvensjonell diagnostikk (5).

Det er realistisk å regne med diagnostiske funn ved neste generasjons sekvensering hos rundt en tredel av pasienter med medfødte syndromer som allerede har vært utredet $i$ henhold til vanlig praksis. Men neste generasjons sekvensering løser ikke alle diagnostiske nøtter. Påviste genvarianter skal tolkes i lys av kliniske funn. For mange pasienter vil ikke metoden være diagnostisk avklarende, og i verste fall kan gal diagnose stilles fordi en uskyldig genvariant mistolkes som patologisk. Kliniske genetikere vil fortsette å være et bindeledd mellom andre spesialister, laboratoriet og forskning. En av deres viktige oppgaver vil bli å fortelle laboratoriet at kartet ikke stemmer med terrenget, dvs. at betydning av en genvariant antakelig er feiltolket. Klinisk syndromdiagnostikk blir derfor langt fra overflødig, kanskje heller enda viktigere enn før, men kommer senere i diagnostiseringsprosessen.

Hvilke ferdigheter må «neste generasjons» kliniske genetikere ha? I tillegg til å være gode klinikere må de være fortrolige med ny sekvenseringsteknologi, ha gode kunnskaper om tolkning av genetiske og genomiske varianter, ha innsikt $\mathrm{i}$ både arveanleggets kompleksitet og biologiske prosesser samt være gode til å formidle.

\section{Trine Prescott}

tripre@ous-hf.no

Trine Prescott (f. 1952) er overlege ved Klinisk seksjon, Avdeling for medisinsk genetikk, Oslo universitetssykehus.

Forfatter har fylt ut ICMJE-skjemaet og oppgir ingen interessekonflikter.

\footnotetext{
Litteratur

1. Kvernmo HD, Haugstvedt J-R. Behandling av medfødte sammenvokste fingre. Tidsskr Nor Legeforen 2013; 133: 1591-5.

2. Baird PA, Anderson TW, Newcombe HB et al. Genetic disorders in children and young adults: a population study. Am J Hum Genet 1988; 42: 677-93.

3. Green RC, Berg JS, Grody WW et al. ACMG recommendations for reporting of incidental findings in clinical exome and genome sequencing. Genet Med 2013 15: $565-74$

4. Saunders CJ, Miller NA, Soden SE et al. Rapid whole-genome sequencing for genetic disease diagnosis in neonatal intensive care units. Sci Transl Med 2012; 4: ra135.

5. Gahl WA, Markello TC, Toro $C$ et al. The National Institutes of Health Undiagno sed Diseases Program: insights into rare diseases. Genet Med 2012; 14: 51 -9.
} 